\title{
Statinadherencia akut koszorúér-esemény után
}

\author{
Simon Attila', Kósa István², Vassányi István ${ }^{3}$, Andrássy Gábor ${ }^{4}$, Erdei Ferenc ${ }^{5}$, \\ Kohut László ${ }^{2}$ Páder Katalin ${ }^{6}$, Simon Éva7, Szász Károly ${ }^{8}$, Veress Gábor1, \\ Tiringer István?
}

\author{
'Balatonfüredi Állami Szívkórház, Balatonfüred, ${ }^{2}$ Magyar Honvédség Egészségügyi Központ - Honvédkórház, \\ Balatonfüredi Kardiológiai Rehabilitációs Intézet, Balatonfüred, ${ }^{3}$ Pannon Egyetem, Müszaki Informatikai Kar, \\ Egészségügyi Informatikai Kutató-Fejlesztő Központ (EIKFK), Veszprém, ${ }^{4}$ Budapesti Szent Ferenc Kórház, \\ Budapest, ${ }^{5}$ Békés Megyei Központi Kórház, Pándy Kálmán Tagkórház, Gyula \\ ${ }^{6}$ Bajcsy-Zsilinszky Kórház és Rendelőintézet, Budapest, ${ }^{7}$ Soproni Erzsébet Oktató Kórház és Rehabilitációs \\ Intézet, Sopron, ${ }^{8}$ Csongrád Megyei Önkormányzat Mellkasi Betegségek Szakkórháza, Deszk \\ 9PTE ÁOK, Magatartástudományi Intézet, Pécs \\ Levelezési cím. \\ Dr. Simon Attila, e-mail: simon.attila@szivkorhaz.hu
}

Akut koszorúér-események után a gyógyszeres szekunder prevenció alapvető eszköze a hatékony koleszterincsökkentés, amelynek alapkészítményei a HMG-CoA-reduktáz-inhibitorok (statinok). Bár a gyógyszercsalád jelentősen képes mérsékelni az éresemények ismétlődését, a betegek kitartása a statinterápiához közismerten gyenge, ami részben indokolhatja a célértékek el nem érését, a magas vaszkuláris morbiditást és mortalitást az ismerten érbetegek között.

Célok: Vizsgálatunkban arra a kérdésre keresünk választ, hogy különböző akut koszorúér-esemény után rehabilitációs kezelésben részesült betegek statinszedési szokásai hogyan alakulnak az önbevallás, illetve a receptkiváltások alapján.

Betegek és módszer: Prospektív, multicentrikus vizsgálatunkban 7 centrumban bevont 445 beteg (kor $61,3 \pm 8,7$ év, $70,1 \%$ férfi) adatait elemeztük, akinél egyaránt rendelkezésre álltak az önbevallásos és receptkiváltáson alapuló egyéves követési adatok. Közülük 289-en szívinfarktus (AMI-csoport), 53-an perkután revaszkularizáció (PCl-csoport), 103-an szívizom-revaszkularizációs műtét (ACBG-csoport) után kerültek bevonásra. Egy évvel később a betegek kérdőívben, vagy telefoninterjú során nyilatkoztak gyógyszeres kezelésükröl. Rendelkezésünkre áltak a receptkiváltás adatai, amely alapján meghatároztuk a gyógyszeradherenciát és -perzisztenciát.

Eredmények: Kiinduláskor szignifikánsan kevesebb beteg részesült statinkezelésben az ACBG-mütött csoportban (egész csoport: 95,1\%; AMI: 96,9\%; PCI: 96,2\%; ACBG: 89,3\%, a csoportok között jelentős az eltérés, $p<0,01$ ). Ugyan-

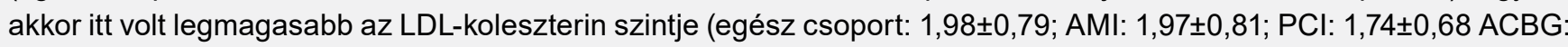
$2,12 \pm 0,75 \mathrm{mmol} / \mathrm{l}$, a csoportok között jelentős az eltérés, $p<0,01)$. Egy évvel később az egész populációban a betegek 83,6\%-a volt statinkezelésen önbevallás alapján (AMI: $85,0 \%$, PCI: 84,3\%, ACBG: 79,4\%), nem találtunk szignifikáns különbséget a csoportok között. A receptkiváltáson alapuló adatok lényegesen rosszabb képet mutattak (a jó adherenciával bíró betegek aránya az egész csoportban: $53,8 \%$, AMI: $57,1 \%$, PCI: $51,9 \%$, ACBG: $44,8 \%$, különbség nem szignifikáns). Többváltozós lineáris regressziós modellben szintén egyik változó sem volt a statinadherencia önálló prognosztikus tényezője. A betegek perzisztenciája is az AMI-csoportban volt a legjobb.

Következtetések: Bár akut koszorúér-betegség utáni rehabilitációban részt vevő betegek nagy arányban részesülnek statinkezelésben, ACBG-mütét utáni betegeknél már kiinduláskor is kisebb arányban van jelen statinkezelés. Egy évvel az esemény után nagyon alacsony a jó adherenciájú betegek aránya.

Kulcsszavak: kardiológiai rehabilitáció, statinadherencia, szekunder prevenció

A kézirat 2020. 09. 01-jén érkezett a szerkesztőségbe, 2020. 10. 20-án került elfogadásra. 


\section{Statin adherence after acute coronary events}

Effective lowering of cholesterol level is the basic element of secondary prevention after acute coronary events. This can be achieved mainly with high dose HMG-CoA reductase inhibitors (statins). Although statins can markedly decrease the risk of repeated vascular events, the patients' poor adherence to this kind of lipid lowering therapy is well known. This can be a reason of high percentage of patients, who do not reach the lipid target values, and can lead to increased cardiovascular morbidity and mortality among patients with former vascular events.

Aims: Our aims were to describe statin adherence (using both self-report and medical dispensation data) among different groups of patients, who participated in cardiac rehabilitation after coronary events.

Patients and methods: In or prospective, multicenter trial we evaluated the statin therapy and 1 year adherence of 445 patients (age: $61.3 \pm 8.7$ year, $70.1 \% \mathrm{men}$ ) where both self-reported statin use and medical dispensation data were available. Patients were included in the trial after acute myocardial infarction (AMI group, 289 patients), after percutaneous coronary intervention (PCl group, 53 patients) or after coronary artery bypass graft operation (ACBG group, 103 patients). 12 months after the discharge from rehabilitation patients were asked about their medication in questionnaires, or in standardized telephone interview. Medical dispensation data, that were available from the medical insurance database allowed us to compute medical adherence and persistence.

Results: Even at the baseline evaluation significantly less patients took statin in the ACBG group (Total population: 95.1\%, AMI: 96.9\%, PCl: $96.2 \%$, ACBG: $89.3 \%, p<0.01$ ). At the same time the LDL cholesterol level was the highest in this group (Total population: $1.98 \pm 0.79$, AMI: $1.97 \pm 0.81$, PCl: $1.74 \pm 0.68$ ACBG: $2.12 \pm 0.75 \mathrm{mmol} / \mathrm{l}, \mathrm{p}<0.01$ ). 12 months later $83.6 \%$ of the total patient population took statins according to self-report, there were no differences between groups (AMI: $85.0 \%$, PCl: $84.3 \%$, ACBG: $79.4 \%$ ). Medical dispensation data described a much worse situation the proportion of patients who took at least $80 \%$ of prescribed medication was $53.8 \%$ in the total population $(57.1 \%$ in AMI, $51.9 \%$ in $\mathrm{PCl}$, and $44.8 \%$ in the ACBG groups, no significant differences). Using a multivariable logistic regression model from the baseline variables neither was significant predictors of the variance of statin adherence. The persistence of the patients was the highest in the AMI group.

Conclusion: Although high percent of patients had statin treatment, the ACBG group had lower rate of treatment even at the baseline. 12 months later the proportion of patients who are adherent to the statins is particularly low.

Keywords: cardiac rehabilitation, statin adherence, secondary preventio

\section{Bevezetés}

Az ateroszklerotikus szívbetegség vezető halálok a nyugati társadalmakban. Már a betegség megjelenése elött fontos lenne az elsődleges megelőzés minél szélesebb körü alkalmazása, az érbetegséghez kapcsolható rizikófaktorok (pl. dohányzás, elhízás, mozgásszegény életmód, stressz) eliminálása, az érszükület kialakulásához kapcsolható társbetegségek (pl. magas vérnyomás, cukorbetegség, hypercholesterinaemia) optimális kezelése. Az érbetegség kialakulása után mindezekre a feladatokra még nagyobb hangsúly kerül. Mégis, az éresemények ismétlődésének esélye, az ebből származó halálozási arány elfogadhatatlanul magas (1).

Az érbetegségek utáni kardiológiai rehabilitációt, ahogy azt a folyamatot bemutató legutóbbi szakmai állásfoglalás címe is jelzi, a szekunder prevenció eszközének tartjuk (2). Alkalmazásával csökkenthető a kardiovaszkuláris morbiditás és mortalitás is. Eszközeivel, a fizikai aktivitás emelésével, tréninggel, az egészségtudatos táplálkozás kialakításával, a dohányzásról való lemondás támogatásával, a társbetegségek megfelelő kezelésével, betegedukációval, egészségpszichológiai intervenciókkal, célértékek kijelölésével, mind egy krónikus betegséggel való eredményes megküzdési folyamat kialakítását kívánjuk elősegíteni. Ennek része a gyógyszeres együttmüködés javítása is.

A Magyar Kardiovaszkuláris Rehabilitációs Társaság (MKT) 2014-ben fogalmazta meg céljai között a gyógyszeres adherencia javítását. Az adherenciát befolyásoló tényezők megismerését, az egyes koszorúér-események utáni terápiás együttműködés leírását, valamint egységesen kimunkált intervencióval a gyógyszeres adherencia javítását tüztük ki célul. Jelen elemzésünkben a kardiológiai rehabilitációs kezelésben részesült, akut koszorúér-esemény utáni betegek statinadherenciájának alakulását mutatjuk be mind a betegek önbevallásán, mind a receptkiváltási adatok alapján.

\section{Betegek és módszer}

A vizsgálat menetét a folyóirat egy korábbi számában már részletesen ismertettük (3). Prospektív, multicentrikus, önkontroll-csoportos vizsgálatunk „Intenzív életmódi képzés koszorúér-esemény utáni rehabilitáció 
során a gyógyszeres adherencia javítása érdekében" címmel ETT TUKEB engedélyt kapott (19950-2/2013/ EKU). Hét rehabilitációs centrum 11 osztálya vett részt a betegek bevonásában. Szívinfarktus, perkután koro-

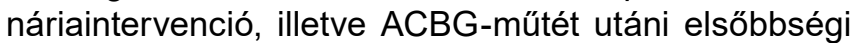
rehabilitációs kezelésre érkező betegeket vontunk be 1:2 arányban a vizsgálat két fázisában. A kellő statisztikai erő biztosításához 1000 beteg programba vonását terveztük. Minden beteg kellő tájékoztatás után írásban nyilatkozott a vizsgálatban való részvételi szándékáról. Az első fázisban standard rehabilitációs kezelés folyt. A második fázisban ezt a gyógyszer-adherenciát javítani célzó standardizált előadásokkal, a beteg figyelmét a célértékekre, életmódi kezelési célokra és figyelmeztető tünetekre figyelmet felhívó kezelőfüzettel, illetve 3 hónappal az esemény után a koleszterincélértékekre figyelmeztető SMS-kampánnyal egészítettük ki. A bevonás után fél évvel, illetve egy év múlva standardizált kérdőíveket küldtünk ki a betegeknek, amelyben rákérdeztünk többek közt gyógyszerszedési szokásaikra is. Akik az egyéves interjút nem küldték vissza, azok körében standardizált telefoninterjút folytattunk, amelynek szintén része volt a gyógyszeres kezelés rögzítése. Ez alapján határoztuk meg az önbevallásos gyógyszeradherenciát. Az eredményeket anonimizálva, a PTE Magatartástudományi Intézetében rögzítettük egy Excel adatbázisban. A vizsgálat elvégzéséhez az MSD Pharma Hungary Kft. nyújtott pénzügyi támogatást az MKRT-nek. A vizsgálók, szerzők pénzügyi támogatásban nem részesültek.

Másik adatforrásunk a Nemzeti Egészségbiztosítási Alap Kezelő (NEAK) volt. A NEAK-nak lejelentett fekvő eseteket, halálozásokat és a gyógyszerkiváltásokat tartalmazó NEAK Tételes Egészségügyi Adattárból (TEA) dolgoztunk. A két forrás egyeztetése alapvetően a kórházi törzsszám és osztálykód alapján történt. Ezen felül az adminisztrációs hibák kiszürése céljából megköveteltük, hogy létezzen a TEA-ban a bevonást végző ellátónál olyan fekvő eset, amelynek felvételi dátuma és távozási dátuma közé esik a klinikai adatbázisban rögzített bevonási dátum (1 nap hibával). Ha egy beteghez több mint egy megfelelő eset tartozott, akkor az időben elsőt tartottuk meg, mint indexesetet. A követés a kórházból való távozás után indult, 365 napig tartott. A perzisztencia korrekt számításához minden betegre külön meg kell határozni azt az időtartamot, amelyet az általa egy alkalommal tipikusan kiváltott tablettaszám le tud fedni. Ezt az időtartamot perzisztenciarésnek nevezzük. A szakmában elfogadott definíció szerint a beteg perzisztenciája azon a napon szünik meg, mikor a követés során legelőször van már legalább perzisztenciarés számú napja gyógyszer nélkül.

A perzisztenciarést a NEAK vénytáblái alapján határoztuk meg minden betegre. Az egy napon ugyanazzal az ATC-vel szereplő több vényt összevontuk egyetlen kiváltásba. Döntetlen esetén, például ha 3 alkalommal 30 és szintén 3 alkalommal 60 tablettát váltott ki, a na- gyobb perzisztenciarést (a példában a 60 napot) adtuk a betegnek.

Az adherencia számításánál úgy jártunk el, hogy figyelembe vettük a receptkiváltások időbeli ütemezését is, tehát egy későbbi nagyobb kiváltás nem teszi jóvá egy korábbi tabletta nélküli időszak hatását. A számításnál a következő képletet használtuk:

Adherenciaarány $=100-$ ([kórházon kívül töltött

napok közül azok száma, amikor nem volt tablet-

tája / kórházon kívül töltött napok száma] × 100).

Adherensnek azt vettük, akinél az adherencia $80 \%$ felett volt.

Mivel vizsgálatunkban az önbevalláson és a receptkiváltáson alapuló adherenciaadatokat kívánjuk összevetni, elemzésünkbe csak azoknak a betegeknek az adatait használtuk, akiknél mindkét módszer alapján rendelkeztünk információval. Ahhoz, hogy az alkalmazott intervenció hatásait kiszürjük, csak a 2. fázis adataival dolgoztunk.

A betegeket 3 bevonási csoportba soroltuk (AMI, ACBG, $\mathrm{PCl}$ ). Az akut infarktusos betegek az AMI-csoportba sorolódtak akkor is, ha az akut fázis után egy héten belül $\mathrm{PCl}$ történt náluk. Az ACBG-csoportba soroltuk őket, ha egy héten belül mütéti revaszkularizációra kerültek. $\mathrm{Az}$ ACBG-mütött betegeket akkor is az ACBG-csoportba soroltuk, ha perioperatív szívinfarktust szenvedtek el, vagy ha egy héten belül $\mathrm{PCl}$ vált szükségessé. Az AMI kapcsán nem különítettük el az ST-elevációval járó és ST-elevációval nem járó kórformát.

Statisztikai elemzés során a független csoportok összehasonlításakor nem paraméteres próbát alkalmaztunk a folytonos változók esetében (mivel ezek KolgomorovSmirnov-teszt alapján eltértek a normál eloszlástól), és khi-négyzet próbát, ha kategoriális változókat hasonlítottunk össze. A 12 hónapos adherencia elörejelzésére bináris logisztikus regressziós modelleket hoztunk létre. A független változók közé kerültek a kiinduláskor vizsgált klinikai paraméterek. A modell kialakításánál a Forward: LR-módszert használtuk. A perzisztenciaadatok elemzéséhez Kaplan-Meier-analízist végeztünk. Az adatok feldolgozásához az IBM SPSS Statistics (23. Verzió) statisztikai programcsomagot használtuk.

\section{Eredmények}

A betegszelekciót az 1. ábra mutatja be. Az 1. fázis betegbevonása 2014. júniustól 2014 októberéig tartott, ezalatt 331 beteget választottunk be. 2014. októbertől 2015. decemberig a 2. fázisba 620 esetet vontunk be. A bevonási hibák, ismételt bevonások után 912 beteg maradt. Kizártuk azokat, akik a bevonás utáni 1 évben kevesebb, mint 300 napot töltöttek kórházon kívül. Végül azoknak a betegeknek az adatait dolgoztuk fel, akik a 2. fázisba kerültek (556), akiknek az önbevallásos (445) adatai rendelkezésre álltak, és akiknél bármely hatóanyag tekintetében voltak receptkiváltáson alapuló 
Vizsgálatba bevont betegek: 951

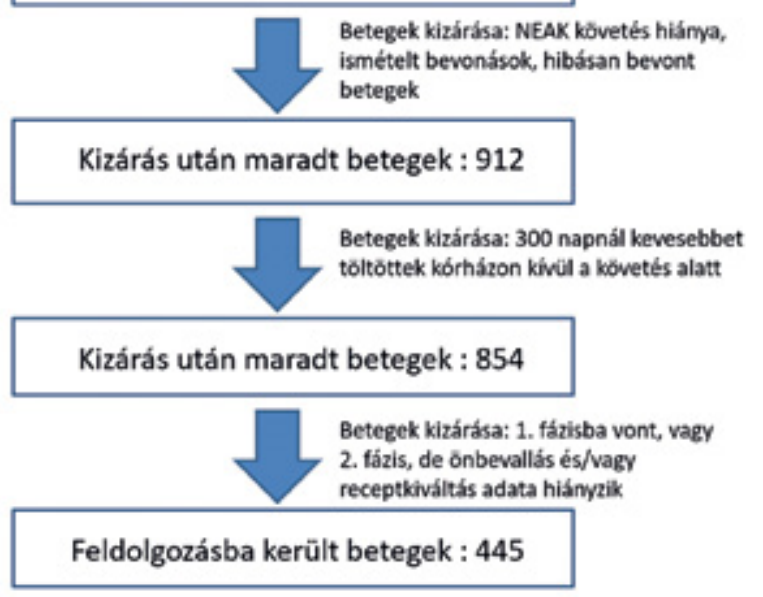

1. ÁBRA. Vizsgálatba vont betegek kiválasztásának folyamata

információink (556). Így 445 beteg adatait analizáltuk. Statinkiváltásra vonatkozó receptadatok 400 betegnél voltak elérhetőek. Az egész betegcsoport, illetve a bevonás alapján képzett 3 betegcsoport jellemző klinikai adatait az 1. táblázat tünteti fel.

A szekunder prevencióhoz a betegek rehabilitációs kezelése során használt lipidcsökkentö-kezelést, valamint az ekkor mért vérzsírértékeket a 2. táblázat mutatja be. $A$ betegek magas arányban részesültek vérzsírcsökkentő-kezelésben. Dominált a statinnal történő kezelés. Ebben azonban jelentős különbségeket találtunk az egyes betegcsoportok között; ACBG-mütét után a betegek sokkal kisebb mértékben kaptak bármely vérzsírcsökkentöt $(p<0,05)$, különösen igaz ez a statinkezelésre $(p<0,01)$. Ezetimib és fibrátok nagyon alacsony arányban kerültek alkalmazásra, e tekintetben a csoportok közt nem volt különbség. Mindez a vérzsír-ered- ményeken is megnyilvánult, az ACBG-mütött csoportban találtuk a legkedvezőtlenebb vérzsírprofilt.

Egyéves követésnél a kérdőívre, vagy telefoninterjúra alapozott megítélés alapján az egész populációban $83,6 \%$-os statinszedési arányt detektáltunk, nem volt számottevő eltérés az egyes csoportok között (AMI: 85,0\%, PCl: 84,3\%, ACBG: 79,4\%). A receptkiváltási adatok azonban egész más képet tárnak elénk. Azon betegek aránya, akik a statinreceptjeiket legalább a kórházon kívül töltött követési időszak $80 \%$-ára kiváltották $53,8 \%$ volt. Különösen alacsony volt az ACBG-csoportban a gyógyszert rendszeresen szedők aránya (44,8\%), amíg AMI után $57,1 \%, \mathrm{PCl}$ után $51,9 \%$ volt a jó adherenciájú betegek aránya, a csoportok közti különbség nem szignifikáns.

Tekintve, hogy a betegcsoportok közt néhány tényezőben (életkor, hipertónia) szignifikáns eltérést találtunk (1. táblázat), illetve, hogy a revaszkularizált csoportban is voltak olyan betegek, akiket korábban szívinfarktussal kezeltek, amely befolyásolhatta gyógyszerszedési szokásaikat, az adherenciával való független kapcsolat megitélésére egy többváltozós bináris regressziós modellt építettünk fel az 1. táblázatban szereplö klinikai tényezőkből. A modell nem szignifikáns $(p=0,07)$, és egyetlen változó sem bizonyult az adherencia önálló prediktorának.

Végül összehasonlítottuk a három csoport statinperzisztenciáját (2. ábra). Az egész mintában mért perziszten-

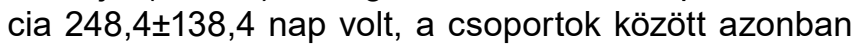
jelentős különbségeket találtunk (AMI: 263,2 $\pm 131,0$, PCl: 218,6 $\pm 146,9$, ACBG: 221,8 $\pm 149,2$ nap, $p<0,05)$. Kaplan-Meier-analízis szerint a három betegcsoport betegei tendenciózusan eltértek egymástól a folyamatos gyógyszerszedés tekintetében $(p=0,051)$. Legnagyobb arányban a szívinfarktus után szedték a betegek a gyógyszert folyamatosan, amely a követés kezdetétől meghaladta a PCl-csoport és az ACBG-mütött betegek gyógyszerkiváltását.

1. TÁBLÁZAT. A betegcsoportok jellemző klinikai adatai

\begin{tabular}{|c|c|c|c|c|c|}
\hline & $\begin{array}{l}\text { Egész csoport } \\
(n=445)\end{array}$ & $\begin{array}{l}\text { AMI után } \\
(n=289)\end{array}$ & $\begin{array}{c}\text { PCI után } \\
(n=53)\end{array}$ & $\begin{array}{l}\text { ACBG után } \\
(n=103)\end{array}$ & $\begin{array}{l}\text { Szigni- } \\
\text { fikancia }\end{array}$ \\
\hline Kor (év) & $61,3 \pm 8,7$ & $60,2 \pm 9,1$ & $62,3 \pm 8,8$ & $63,9 \pm 6,7$ & $p<0,002$ \\
\hline Férfinem (\%) & $312(70,1 \%)$ & $200(69,2 \%)$ & $34(64,2 \%)$ & $78(75,7 \%)$ & ns \\
\hline $\begin{array}{l}\text { Diabetes mellitus (nincs/pre- } \\
\text { diabétesz/diabétesz) }\end{array}$ & $\begin{array}{c}287(66,0 \%) \\
22(5,5 \%) \\
126(29,0 \%)\end{array}$ & $\begin{array}{c}196(69,0 \%) \\
15(5,3 \%) \\
73(25,7 \%)\end{array}$ & $\begin{array}{c}31(63,3 \%) \\
1(2,0 \%) \\
17(34,7 \%)\end{array}$ & $\begin{array}{c}60(58,8 \%) \\
6(5,9 \%) \\
36(35,3 \%)\end{array}$ & ns \\
\hline Hipertónia & $358(82,1 \%)$ & $223(78,5 \%)$ & $48(96,0 \%)$ & $87(85,3 \%)$ & $p<0,01$ \\
\hline Perifériás verőérbetegség & $36(8,3 \%)$ & $20(7,1 \%)$ & $5(10,2 \%)$ & $11(10,7 \%)$ & ns \\
\hline Szívelégtelenség & $38(8,8 \%)$ & $21(7,5 \%)$ & $6(12,2 \%)$ & $11(10,9 \%)$ & ns \\
\hline Stroke a kórtörténetben & $21(4,8 \%)$ & $12(4,2 \%)$ & $1(2,0 \%)$ & $8(7,8 \%)$ & ns \\
\hline Balkamrai ejekciós frakció \% & $56,0 \pm 10,3$ & $55,7 \pm 10,6$ & $58,1 \pm 10,5$ & $55,5 \pm 9,3$ & ns \\
\hline $\begin{array}{l}\text { Dohányzás (soha/ex/lemon- } \\
\text { dóban /jelenleg is) }\end{array}$ & $\begin{array}{c}138(31,8 \%) \\
213(49,1 \%) \\
67(15,4 \%) \\
16(3,7 \%)\end{array}$ & $\begin{array}{c}90(31,7 \%) \\
132(46,5 \%) \\
51(18,0 \%) \\
11(3,9 \%)\end{array}$ & $\begin{array}{c}16(31,4 \%) \\
27(52,9 \%) \\
5(9,8 \%) \\
3(5,9 \%)\end{array}$ & $\begin{array}{c}32(32,3 \%) \\
54(54,5 \%) \\
11(11,1 \%) \\
2(2,0 \%)\end{array}$ & ns \\
\hline Szívinfarktus a kórtörténetben & $331(74,4 \%)$ & $289(100 \%)$ & $12(22,6 \%)$ & $30(29,1 \%)$ & $p<0,001$ \\
\hline
\end{tabular}


2. TÁBLÁZAT. A betegcsoportokban a rehabilitáció során alkalmazott lipidcsökkentő-kezelés és az ekkor mért lipidértékek

\begin{tabular}{|l|c|c|c|c|c|}
\hline & $\begin{array}{c}\text { Egész csoport } \\
\text { (n: 445) }\end{array}$ & $\begin{array}{c}\text { AMI után } \\
\text { (n: 289) }\end{array}$ & $\begin{array}{c}\text { PCI után } \\
\text { (n: 53) }\end{array}$ & $\begin{array}{c}\text { ACBG után } \\
\text { (n: 103) }\end{array}$ & Szignifikancia \\
\hline $\begin{array}{l}\text { Bármely lipidcsökkentő } \\
\text { szedése }\end{array}$ & $425(95,5 \%)$ & $281(97,2 \%)$ & $51(96,2 \%)$ & $93(90,3 \%)$ & $p<0,05$ \\
\hline Statinszedés & $423(95,1 \%)$ & $280(96,9 \%)$ & $51(96,2 \%)$ & $92(89,3 \%)$ & $p<0,01$ \\
\hline Ezetimibszedés & $19(4,3 \%)$ & $13(4,5 \%)$ & $0(0,0 \%)$ & $6(5,8 \%)$ & $n s$ \\
\hline Fibrátszedés & $6(1,3 \%)$ & $5(1,7 \%)$ & $1(1,9 \%)$ & $0(0,0 \%)$ & $n s$ \\
\hline Összkoleszterin (mmol/l) & $3,68 \pm 0,89$ & $3,68 \pm 0,89$ & $3,43 \pm 0,79$ & $3,80 \pm 0,94$ & $p<0,05$ \\
\hline LDL-koleszterin (mmol/l) & $1,98 \pm 0,79$ & $1,97 \pm 0,81$ & $1,74 \pm 0,68$ & $2,12 \pm 0,75$ & $p<0,01$ \\
\hline HDL-koleszterin (mmol/l) & $1,03 \pm 0,34$ & $1,06 \pm 0,31$ & $1,13 \pm 0,32$ & $0,89 \pm 0,37$ & $p<0,001$ \\
\hline Triglicerid (mmol/l) & $1,59 \pm 0,85$ & $1,52 \pm 0,86$ & $1,41 \pm 0,68$ & $1,90 \pm 0,86$ & $p<0,001$ \\
\hline
\end{tabular}

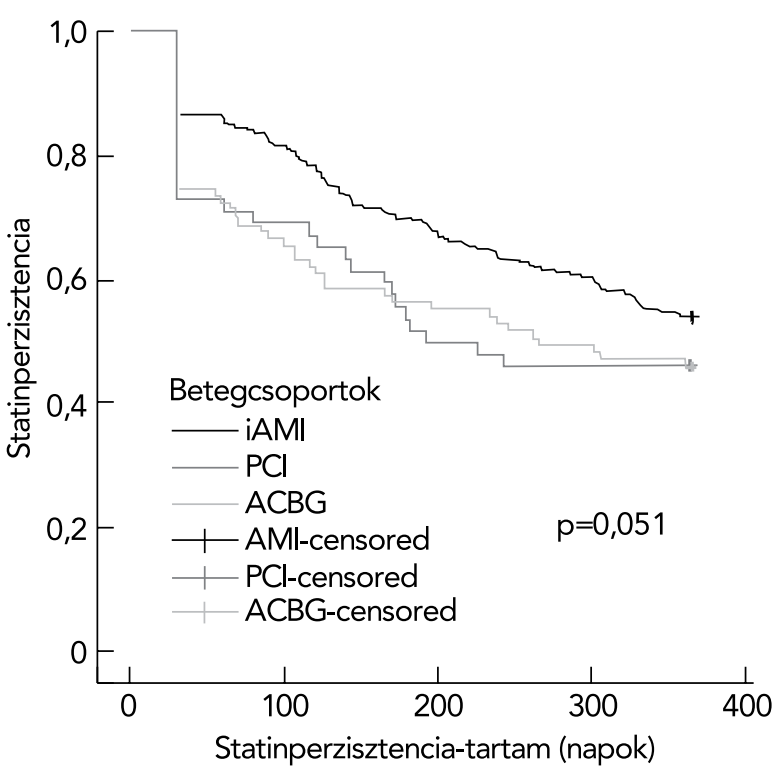

2. ÁBRA. Statinperzisztencia a három betegcsoportban (AMl: szívinfarktus után, PCl: katéteres tágítás után, ACBG: szívizom revaszkularizációs mútét után)

\section{Megbeszélés}

Vizsgálatunk egy olyan populációban történt, amely két szempontból is speciális. Egyrészt a bevonás helyszíne intézeti kardiológiai rehabilitáció volt. A magyar betegek csak kis arányban vesznek részt kardiológiai rehabilitációban $(4,5)$, így feltételezhetünk egyfajta betegszelekciót (az életmód-terápiára nyitottabb, esetleg magasabb szocioökonómiai státuszú betegek). A kardiológiai rehabilitáció önmagában is javítja a gyógyszeradherenciát (6). Másrészt, bár minden ellátóhelyen folyik betegedukáció, amelynek része a gyógyszeres szekunder prevenció javítása, a vizsgálatban résztvevő 7 centrum összehangolta ez irányú tevékenységét, egységesen, magas színvonalon nyújtották ezt a programelemet. Jelenleg nincs bizonyítékunk arra, hogy az intervenció fokozta volna a gyógyszer-adherenciát a standard rehabilitációs szolgáltatáshoz képest. Mégis, a Magyar Kardiológusok Társasága szervezésében a vizsgálat után elinduló „Túlélési ismeretek szívinfarktust követően" program a vizsgálatunkban alkalmazotthoz hasonló struktúrával épült fel és jelenleg is számos rehabilitációs intézményben folyik. Így feltételezhetjük, hogy adataink reprezentálják a jelenlegi hazai viszonyokat, vagy egy kissé jobb képet tükrözhetnek, mint ami az egész betegcsoportra jellemző.

Elemzésünk elsődleges célja a gyógyszer-adherencia jellemzése volt. Míg korábbi feldolgozásunkban (3) ennek elsődlegesen pszichoszociális hátterét próbáltuk felfedni, most a különböző koszorúér-események utáni gyógyszerszedési szokásokat kívántuk jellemezni, feltételezve, hogy a csoportok eltérhetnek egymástól. A legtöbb szekunder prevencióval foglalkozó irányelv (7, $8,9)$ egységesen kezeli a lezajlott érbetegséget, egy évvel az akut esemény után hasonló kezelési és megelőzési elveket fogalmaz meg.

$A z$ érbetegségek magas ismétlődési kockázatának háttere komplex. A kockázat egy részéért ma még nem, vagy csak kevéssé változtatható rizikótényezők tehetők felelőssé. Ide kell sorolnunk a genetikai rizikót, a magasabb gyulladásos értékekhez asszociált kockázatot (bár e téren már vannak sikeresen zárult vizsgálatok) $(10,11)$, környezeti tényezőket (pl. légszennyezettség) (12) és egyes személyiségvonásokat is (13). Ha a befolyásolható standard rizikófaktorokat megfelelően kontrolláljuk is, a reziduális kockázat mértéke a SMART-rizikó score alapján kb. 10\% 10 év vonatkozásában (14). $A z$ érbetegségek ismétlődésének jelentős része azonban az ismert, befolyásolható rizikófaktorokhoz köthető, amelyet az éresemények megjelenése után sem tudunk megfelelően kontrollálni. Az EUROASPIRE-vizsgálatok sora immár majd' két évtizede vizsgálja ezt a kérdést. A sorban egymást követő elemzés alapján is azt láthatjuk, hogy a korábban dohányzók kb. 50\%-a egy évvel az éresemény után is dohányzik, kb. $80 \%$-a túlsúlyos és bár lassan emelkedik a hipertónia kontrollja, ez még a IV. felmérésben is csak $55,3 \%$ volt (15).

Az érrendszeri kockázat jelentős része mind primer, mind szekunder prevencióban az emelkedett koleszterin, különösen az LDL-koleszterin-szinthez köthető. A lipidcé- 
lok eléréséhez az életmódi tényezőkön túl nagy dózisú statinkezelésen, kombinációk (ezetimib, PCSK9-gátlók) alkalmazásán keresztül vezethet az út. Mégis, még az alapnak tekinthető statinkezelés tekintetében is jelentős kihívásokkal kell szembenéznünk. A gyógyszercsaládot illetően különösen rossznak mondható a betegek terápiahüsége mind primer (16), mind szekunder prevenció során $(16,17,18)$. A statin-nonadherencia jelentősen emeli a kardiovaszkuláris kockázatot $(17,19,20)$, a halálozási arányt szívinfarktus után (16, 20, 21). Ez egyrészt a célérték feletti lipidértékekkel magyarázható, másrészt úgy tekinthetünk a statin-nonadherenciára, mint a krónikus verőérbetegséggel való eredménytelen megküzdés markerére, ami más megküzdési folyamatok (többi gyógyszer folyamatos szedése, gondozásban való részvétel, dohányzás kerülése, rendszeres testmozgás, egészségtudatos táplálkozás stb.) eredménytelenségét is elöre vetíti $(6,22,23)$. A statinadherencia megítélése is nehéz. A klinikusok leginkább a betegek nyilatkozatára támaszkodhatnak, ami lényegesen jobb képet vetíthet elénk, mint az objektívebb, a receptkiváltásból származó adatokon alapuló megítélés.

Az EUROASPIRE-vizsgálatok alapján az akut vaszkuláris esemény után egy évvel kaphatunk képet a gyógyszeres szekunder prevencióról is. A II-IV. vizsgálatok összehasonlításából láthatjuk, hogy jelentős arányban emelkedett ugyan a vérzsírcsökkentő kezelésben részesülők aránya (15), az V. vizsgálatban a betegeknek mégis alig ötöde érte el a korábbi irányelvben megfogalmazott (24) 1,8 mmol/l LDL-koleszterin-célértéket (25). A MULTI GAP 2012 vizsgálatban a többségében lezajlott CV-esemény miatt igen magas CV-rizikóval bíró betegek körében is csak a betegek $22 \%$-a érte el az akkori 1,8 mmol// LDL-koleszterin-célértéket (16). $A z$ elért LDL-koleszterin-szint és az adherencia fordítottan arányosak voltak egymással. Az új irányelv (7) pedig ennél lényegesen szigorúbb célt fogalmaz meg, $1,4 \mathrm{mmol} / \mathrm{l}-\mathrm{t}$ (illetve a kiindulási érték legalább $50 \%$-os csökkentését) tűzi ki célul, illetve két éven belüli éresemény ismétlésénél megfontolható az 1,0 mmol/l célértékre való törekvés is. Az önbevallás alapján magas statinhasználat tehát nem elegendő a lipidcélok eléréséhez. E mögött egyaránt állhat nem megfelelő dózisválasztás, vagy a betegek alacsony adherenciája.

Bár az egész csoportban egy évvel az esemény után önbevallás alapján mért adataink szinte teljesen megegyeznek az EUROASPIRE IV vizsgálatban hasonló összetételü betegcsoportjában mért 88\%-kal (15), a receptkiváltások elemzésével egészen más képet kaptunk a gyógyszerszedésről.

A legtöbb hazai szekunder prevenciós vizsgálatban a lezajlott esemény, amely után a szekunder prevenciós statinadherenciát a betegek receptkiváltási adatai alapján megítélték, az leginkább akut koronáriaszindróma, szívinfarktus volt $(17,18,26)$. Jermendy és munkatársai 5590 ACS-en átesett beteg csoportjában 2007-2009 között receptkiváltáson alapuló 50\%- os egyéves statinperzisztencia arányt detektált (26). Tomcsányi 2013-2015 évi adatgyüjtésében szívinfarktus után a betegek átlagosan $70 \%$-át találta statinadherensnek (18). Jánosi és munkatársai 2013-2014 között a Nemzeti Szívinfarktus Regiszterben azonosított 14843 szívinfarktust elszenvedett beteg adatait elemezték (17). Egy évvel az esemény után jó adherenciát mindössze a betegek $54,4 \%$-ában detektáltak. A vizsgálatunkban mért $57,1 \%$ tehát beleilleszkedik a magyar adatok sorába.

Tudtunkkal vizsgálatunk az első olyan magyar felmérés, amely a revaszkularizációs kezelésben részesült betegek statinadherenciáját mutatja be receptkiváltási adatok alapján. Az ACBG-mütött betegek önbevalláson alapuló adherenciája nem tért el számottevően a többi csoporttól. A receptkiváltás alapján sem volt szignifikánsan alacsonyabb, mint a másik két csoportban. A perzisztens betegek aránya tendenciaszinten alacsonyabb volt a revaszkularizált csoportokban, a folyamatos szedés időtartama pedig számottevően eltért, szintén a revaszkularizált csoportokban volt alacsonyabb. Ez azért is különösen aggasztó, mert ACBG-mütét után éppúgy megfigyelhető a nonadherens betegek magasabb eseményrátája (27), mint akut koronáriaszindróma után. Már vizsgálatba vonáskor alacsonyabb arányban részesültek statinkezelésben a mütött betegek. Ezt a hátrányt részben magyarázhatja, hogy ez a betegcsoport idősebb volt, közel harmaduknál már zajlott le szívinfarktus. Így egyrészt koruknál fogva esendőbbek lehettek a mellékhatásokra, másrészt kórtörténetük során tapasztalhattak meg olyan eltérést, amelyet statinasszociáltnak tarthattak és emiatt nem kapták a hatóanyagot. Simonyi és munkatársai ugyanakkor a MUTIGAP 2013 vizsgálatban az orvos szerepét is kiemelik a lipidcsökkentő-kezelés kezdésében és fenntartásában (28), jelen esetben ez egyaránt jelenti a szívsebészetet, rehabilitációt, háziorvoslást és a területi kardiológiai gondozást. Kulik és munkatársai az ACBG-mútét után egy hónappal statint szedők között a nem szedőkhöz képest jelentősen alacsonyabb halálozást [hazard ratio (HR) 0,82, 95\% confidence interval (CI) 0,72-0,94], illetve adverz kardiovaszkuláris eseményrátát [HR 0,89, 95\% Cl: 0,81-0,98] találtak (29). Björklund és munkatársai a SWEDEHEART-adatbázis alapján 28812 izolált ACBG-mütéten átesettek beteg sorsát elemezték (27). Műtét utáni időszakban a betegek 93,9\%-a kapott statint (ami meghaladta a jelen vizsgálatban általunk mért 89,3\%-ot). 8 évvel a mútét után a betegek $77,3 \%$-a még statinkezelésben részesült. A statinadherencia jelentősen alacsonyabb halálozási kockázattal járt (HR 0,56, 95\% Cl: 0,52-0,60). Irodalmi adatok is megerősítik, hogy ACBG-mütét után kevésbé részesülnek a betegek hatékony szekunder prevenciós kezelésben, mint például $\mathrm{PCl}$-kezelésben részesülők $(30,31)$. Elemzésünk arra hívja fel a figyelmet, hogy erre a betegcsoportra a jelenleginél lényegesen nagyobb figyelmet kell fordítanunk. 


\section{Következtetés}

Bár akut koszorúér-betegség utáni rehabilitációban részt vevő betegek nagy arányban részesülnek statinkezelésben, ACBG-mütét utáni betegeknél már kiinduláskor is kisebb arányban van jelen statinkezelés. Egy évvel az esemény után alacsony a jó adherenciájú betegek aránya. A revaszkularizáció után rosszabb a betegek folyamatos gyógyszerszedési szokása.

\section{Nyilatkozat \\ A szerzök kijelentik, hogy az eredeti közlemény megírásával kapcsolatban nem áll fenn velük szem- ben pénzügyi vagy egyéb lényeges összeütközés, összeférhetetlenségi ok, amely befolyásolhatja a közleményben bemutatott eredményeket, az abból levont következtetéseket vagy azok értelmezését.}

Irodalom

1. Levitan EB, Muntner P, Chen L, et al. Burden of coronary heart disease rehospitalizations following Acute myocardial infarction in older adults. Cardiovasc Drugs Ther 2016; 30(3): 323-331.

https://doi.org/10.1007/s10557-016-6653-6

2. Ambrosetti M, Abreu A, Corra U, et al. Secondary prevention through comprehensive cardiovascular Rehabilitation: From knowledge to implementation. 2020 update. A position paper from the Secondary Prevention and Rehabilitation Section of the European Association of Preventive Cardiology. European Journal of Preventive Cardiology 2020; (0): 1-42. https://doi.org/10.1177/2047487320913379

3. Tiringer I, Andrássy G, Erdei $F$, et al. A korai rehabilitációban résztvevő iszkémiás szívbetegek gyógyszeres adherenciáiának pszichoszociális tényezői. Egy multicentrikus követéses vizsgálat eredményei. Cardiologia Hungarica 2017; 47: 419-424.

https://doi.org/10.26430/CHUNGARICA. 2017.47.6.419

4. Boncz I, Sebestyén A, Csákvári T, et al. A kardiológiai rehabilitáció teljesítménymutatói Magyarországon. Orv Hetil 2019; 160(Suppl 1): 6-12. https://doi.org/10.1556/650.2019.31410

5. Bjarnason-Wehrens B, mcgee H, Zwisler AD, et al. Cardiac rehabilitation in Europe: Results from the European Cardiac Rehabilitation Inventory Survey. Eur J Cardiovasc Prev Rehabil 2010; 17(4): 410-8. https://doi.org/10.1097/HJR.0b013e328334f42d

6. Shah ND, Dunlay SM, Ting HH, et al. Long-term Medication Adherence after Myocardial Infarction: Experience of a community Am J Med 2009; 122(10): 961.e7-961.13. https://doi.org/10.1016/j.amjmed.2008.12.021

7. Mach F, Baignet C, Catapano AL, et al. 2019 ESC/EAS Guidelines for the management of dyslipidaemias: lipid modification to reduce cardiovascular risk. Eur Heart J 2019; 00: 1-78.

https://doi.org/10.1093/eurhearti/ehz455

8. Knuuti J, Wijns W, Saraste A, et al. 2019 ESC Guidelines for the diagnosis and management of chronic coronary syndromes. Eur Heart $J$ 2019; 00: 1-71. https://doi.org/10.1093/eurheartj/ehz425

9. Piepoli MF, Hoes AW, Agewall S, et al. 2016 European Guidelines on cardiovascular Disease prevention in clinical practice. Eur Heart 2016; 37 2315-2381. https://doi.org/10.1093/eurheartj/ehw106 10. Tardif J-C, Kouz S, Waters DD, et al. Efficacy and Safety of LowDose Colchicine after Myocardial Infarction. N Engl J Med 2019; 381 2497-2505. https://doi.org/10.1056/nejmoa1912388

11. Ridiker PM N, Everett BM, Thuren T, et al. Antiinflammatory Therapy with Canakinumab for Atherosclerotic Disease N Engl J Med 2017; 377: 1119-1131. https://doi.org/10.1056/nejmoa1707914

12. Argacha JF. Air pollution and myocardial infarction. Eur Heart $\mathrm{J}$ 2017: 38: 141. https://doi.org/10.1093/eurheartj/ehw622

13. Martens EJ, Mols F, Burg MM, Denollet J. Type D personality predicts clinical events after myocardial infarction, above and beyond disease severity and depression. The Journal of Clinical Psychiatry 2010; 71(6): 778-783. https://doi.org/10.4088/JCP.08m04765blu

14. Kaasenbrood L, Boekholdt SM, van der Graaf $Y$, et al. Distribution of Estimated 10-Year Risk of Recurrent Vascular Events and Residual Risk in a Secondary Prevention Population. Circulation 2016; 134: 1419 1429. https://doi.org/10.1161/CIRCULATIONAHA.116.021314

15. Kotseva K, De Bacquer G, Jennings $C$, et al. Time Trends in Lifestyle, Risk Factor Control, and Use of Evidence-Based Medications in
Patients With Coronary Heart Disease in Europe Results From 3 EUROASPIRE Surveys 1999-2013. Glob Heart 2017; 12(4): 315-322. e3. https://doi.org/10.1016/j.gheart.2015.11.003

16. Márk L, Reiber I, Parragh G, et al. Lipidcsökkentő kezelés - MULTI GAP 2012 A betegek terápiás együttmüködése, statin-perzisztencia. Metabolizmus 2013; 11: 177-182.

17. Jánosi $A$, Ofner $P$, Kiss $Z$, et al. Szívinfarktust túlélt betegek terápiahüsége a másodlagos megelözés szempontjából fontos gyógyszeres kezelésekhez. Orv Hetil 2017; 158(27): 1051-1057.

https://doi.org/10.1556/650.2017.30795

18. Tomcsányi J. Statin gyógyszerszedési gyakorlat myocardialis infarctus után Magyarországon. Orv Hetil 2017; 158(12): 443-446. https://doi.org/10.1556/650.2017.30687

19. Blackburn DF, Dobson RT, Blackburn JL, Wildon TV. Cardiovascular Morbidity Associated with Nonadherence to Statin Therapy. BJP 2012; 25: 1035-1043. https://doi.org/10.1592/phco.2005.25.8.1035

20. Tuppin P, Neumann A, Danchin N, de Peretti C, et al. Evidencebased pharmacotherapy after myocardial infarction in France: adherence-associated factors and relationship with 30-month mortality and rehospitalization. Arch Cardiovasc Dis 2010; 103: 363-375.

https://doi.org/10.1016/j.acvd.2010.05.003

21.Khalaf $\mathrm{K}$, Johnell $\mathrm{K}$, Austin $\mathrm{PC}$, et al. Low adherence to statin treatment during the $1^{\text {st }}$ year after an acute myocardial infarction is associated with increased $2^{\text {nd }}$-year mortality risk - an inverse probability of treatment weighted study on 54872 patients, European Heart Journal - Cardiovascular Pharmacotherapy pvaa010,

https://doi.org/10.1093/ehjcvp/pvaa010

22. Hope FH, Binkley GM, Fenton S, et al. Systematic review of the predictors of statin adherence for the primary prevention of cardiovascular disease. Plos One 2019; 14(1): e0201196.

https://doi.org/10.1371/journal.pone.0201196

23. Faridi KF, Peterson ED, mccoy LA, Thomas L, Enriquez J, Wang TY. Timing of first postdischarge follow-up and medication adherence after acute myocardial infarction. JAMA Cardiol 2016; 1(2): 147-155 https://doi.org/10.1001/jamacardio.2016.0001.

24. Catapano AL, Graham I, De Backer G, et al. 2016 ESC/EAS Guidelines for the management of dyslipidaemias. Eur Heart J 2016; 37: 2999-3058. https://doi.org/10.1093/eurheartj/ehw272 ehw272

25. Kotseva K, De Backer G, De Bacquer G, et al. Lifestyle and impact on cardiovascular risk factor control in coronary patients across 27 countries: Results from the European Society of Cardiology ESC-EORP EUROASPIRE V registry. European Journal of Preventive Cardiology 2019, 26(8): 824-835. https://doi.org/10.1177/2047487318825350 26. Jermendy Gy, Wittmann I, Nagy L, et al. Az orális antidiabetikum terápia perzisztenciája hazai cukorbetegek körében 2007-2009 között. Metabolizmus 2011; 9: 21-27.

27. Björklund E, Nielsen SJ, Hansson EC, et al. Secondary prevention medications after coronary artery bypass grafting and long-term survival: a population-based longitudinal study from the SWEDEHEART registry. European Heart Journal 2020; 41: 1653-1661.

https://doi.org/10.1093/eurheartj/ehz714

28. Simonyi G. Lipid-lowering therapy and patient adherence in the MULTI GAP 2013 trial. [Lipidcsökkentő terápia és betegadherencia a MULTI GAP 2013 vizsgálat tükrében.] Orv Hetil 2014; 155(17): 669-675. https://doi.org/10.1556/oh.2014.29905

29. Kulik A, Brookhart MA, Levin R, et al. Impact of Statin Use on Outcomes After Coronary Artery Bypass Graft Surgery. Circulation 2008; 118: 1785-1792.

https://doi.org/10.1161/CIRCULATIONAHA.108.799445

30. Hlatky MA, Solomon MD, Shilane D, et al. Use of medications for secondary prevention after coronary bypass surgery compared with percutaneous coronary intervention. J Am Coll Cardiol 2013; 61 : 295-301. https://doi.org/10.1016/j.jacc.2012.10.018

31. Iqbal J, Zhang YJ, Holmes DR, et al. Optimal medical therapy improves clinical outcomes in patients undergoing revascularization with percutaneous coronary intervention or coronary artery bypass grafting: insights from the Synergy Between Percutaneous Coronary Intervention with TAXUS and Cardiac Surgery (SYNTAX) trial at the 5-year follow-up. Circulation 2015; 131:1269-1277.

https://doi.org/10.1161/CIRCULATIONAHA.114.013042 